HortSCIENCE 26(7):928-929. 1991.

\section{'Valcos': A Cos Lettuce Cultivar for Southern Texas}

\author{
P.W. Leeper ${ }^{1}$ and B. Scully ${ }^{2}$ \\ Texas A\&M University Research Center, Weslaco, TX 78596-8399
}

Additional index words. Lactuca sativa, tipburn resistance, downy mildew, pedigree breeding

The lettuce (Lactuca sativa L.) industry in the Lower Rio Grande Valley (LRGV) of southern Texas began in 1946 with $\approx 165$ ha, which, 5 years later, had risen to 6200 ha. Since that time, production has ranged from 250 to 8000 ha, with current production of $\approx 1000$ ha. Lettuce in the LRGV is primarily produced for the U.S. winter market, and is shipped from November through April. To maintain this harvest duration, three planting periods are required: mid-September to early October; mid-October to mid-November; and late November to mid-December. Each planting period requires specifically adapted cultivars. Most of this production is of the crisphead type. Cos types are a minor part of the total production area, but are routinely integrated into the head lettuce cropping system during the second and third planting periods.

The purpose of our breeding program was to develop a cos lettuce with resistance to premature bolting, reduced susceptibility to tipburn, and resistance to Texas races 5 and 6 of downy mildew (Bremia lactucae Regl.), commonly found in southern Texas. An additional objective was to enlarge the array and diversity of lettuce cultivars available to growers in the region. The name 'Valcos' indicates a cos or romaine cultivar for the Rio Grande Valley of Texas.

\section{Origin}

'Valcos' was developed by a combination of the bulk and pedigree methods that included two hybridizations (Fig. 1). The first cross was made in 1968 using Tex 641-196768 as the female parent. This breeding line

Received for publication 21 Aug. 1989. TAES Technical Article no. 25434. This research was supported in part by the South Texas Lettuce Committee. We thank Oswaldo E. Ochoa, Dept. of Vegetable Crops, Univ. of California, Davis, for evaluation of resistance to downy mildew pathotypes. The cost of publishing this paper was defrayed in part by the payment of page charges. Under postal regulations, this paper therefore must be hereby marked advertisement solely to indicate this fact.

${ }^{1}$ Professor Emeritus.

${ }^{2}$ Assistant Professor. Presently Assistant Professor, Everglades Research and Education Center, IFAS, Univ. of Florida, Belle Glade, FL 334308003 . was selected out of PI 274369, which was introduced from Poland in 1961. PI 274369 is a white-seeded Boston-type lettuce with yellowish-green leaves. The PI 274369 stock carries resistance to Texas races 5 and 6 , California pathotypes Ia (isolate C83E11) and II (isolate C83P24), and European isolates SF3 and CG1, but is susceptible to California pathotype III (isolate C83M47) and European isolates SF5, CS9, and CS12 of downy mildew (Farrara and Michelmore, 1987; Ilott et al., 1987; Jones and Leeper, 1971; Sleeth and Leeper, 1966). The male parent was 'Valmaine', a horticulturally desirable cos lettuce with resistance to Texas race 5 of downy mildew (Leeper, 1963). In the $\mathrm{F}_{3}$ generation, line 1157-1 was selected for horticultural type and resistance to downy mildew. 'Valrio', a crisphead type, was crossed as the male parent to line $1157-1$ because it resisted premature bolting compared with 'Valmaine', carried resistance to U.S. race 5 of downy mildew, and tolerated light frost (Leeper, 1969). Resistance to downy mildew in 'Valmaine' and 'Valrio' was originally derived from PI 167150 and PI 91532, respectively, and is conferred by the $D m-5 / 8$ gene (Hulbert and Michelmore, 1985; Johnson et al., 1978; Zink and Duffus, 1969). In 1967, a Texas race 6-resistant breeding line extracted from PI 274369 was designated Tex 641-1967-68 and is the putative source of Dm-6. A 1990 evaluation of PI 274369 stock indicated, however, the presence of $D m-2$ and Dm-4 genes but not Dm-6 (O.E. Ochoa, personal communication).

Single-parent pedigree selection was practiced in the $\mathrm{F}_{2}$ and $\mathrm{F}_{3}$ generations following the first and second crosses (Fig. 1). An array of lines with resistance to downy mildew was selected in the $\mathrm{F}_{6}$ and carried forward as an unselected bulk population until $\mathrm{F}_{11}$. Single plants were again selected in the $F_{11}$ and field tested in the $F_{12}$ and subsequent generations. 'Valcos' was derived from an $\mathrm{F}_{12}$ individual selected in the $\mathrm{F}_{6}$ bulk population 339-1. 'Valcos' was evaluated in three site-year environments.

\section{Description}

'Valcos' is a romaine type lettuce plant 30 to $35 \mathrm{~cm}$ tall, and usually $5 \mathrm{~cm}$ shorter than 'Valmaine'. The heads of 'Valcos' are more compact than either 'Valmaine' or 'Parris Is- land', with 25 to $30 \mathrm{~cm}$ outer head leaves and head diameter of 8 to $10 \mathrm{~cm}$. Wrapper leaves are darker green than those of 'Parris Island' and similar to those of 'Valmaine'. Center leaves are a deep bright yellow, with dark green outer leaves. Leaf midribs are straight, while leaf margins are slightly savoyed with serrations that average 1 to 3 $\mathrm{mm}$. In our judgment, leaf texture, crispness, thickness, and flavor are equivalent to 'Valmaine'. Seed is black.

'Valcos' carries resistance to Texas races 5 and 6, California Ia (isolate C83E11), European races SF5, CG1, and CS12, but is susceptible to California pathotype 11 (isolate C83P24), III (isolate C83M47), and European isolate CS9 of downy mildew (Farrara and Michelmore, 1987; Ilott et al., 1987; Jones and Leeper, 1971; Sleeth and Leeper, 1966). The $D m-5 / 8$ gene in 'Valcos' is derived from 'Valmaine' and 'Valrio', while Dm-6 is presumed to have originated from variation in PI 274369 (Tex 641-1967-68). 'Valcos' has greater resistance to premature bolting and frost damage than either 'Valmaine' or 'Parris Island'. Tipburn resistance is similar to these standard cultivars. Average fresh weight yield of 'Valcos' is signif-

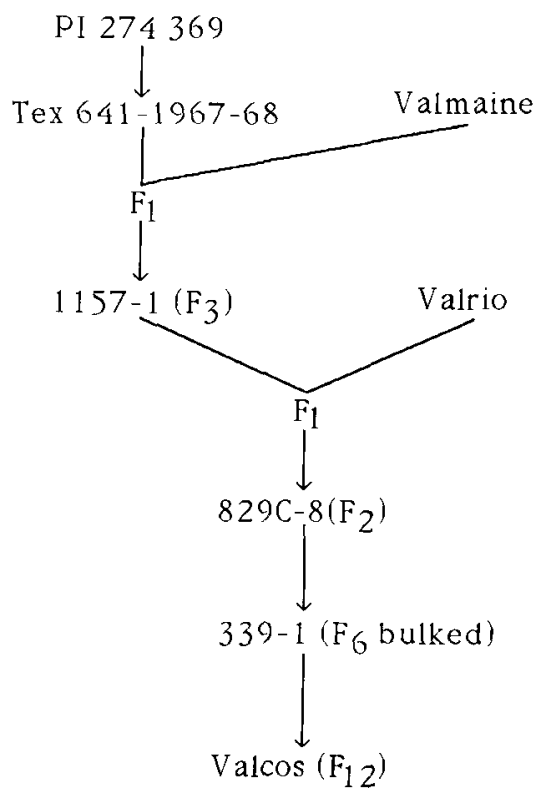

Fig. 1. Pedigree of 'Valcos', a cos lettuce cultivar.

Table 1. Yield traits of 'Valcos' and two of the standard cos cultivars grown in the Lower Rio Grande Valley of Texas. ${ }^{z}$

\begin{tabular}{lcc}
\hline \hline & \multicolumn{2}{c}{ Mean \pm SE } \\
\cline { 2 - 3 } Cultivar & $\begin{array}{c}\text { Fresh yield } \\
\left(\mathrm{t} \cdot \mathrm{ha}^{-1}\right)\end{array}$ & $\begin{array}{c}\text { Head wt } \\
(\mathrm{kg} / \mathrm{head})\end{array}$ \\
\hline Valcos & $36.36 \pm 2.99$ & $0.65 \pm 0.10$ \\
Valmaine & $19.83 \pm 9.80$ & $0.72 \pm 0.43$ \\
Parris Island & $36.12 \pm 0.67$ & $0.69 \pm 0.12$ \\
\hline
\end{tabular}

${ }^{2}$ Based on single sites over 3 years, with two replications per site. 
icantly higher than for 'Valmaine', but similar to that of 'Parris Island' (Table 1). Differences in average head weight of all three cultivars were insignificant. The lower standard errors associated with the yield of 'Parris Island' and the head mass of 'Valcos' and 'Parris Island' suggest that these traits are more stable across environments for these cultivars than for 'Valmaine' (Table 1).

\section{Availability}

Foundation seed was distributed to 10 seed companies and deposited with the Foundation Seed Service of Texas A\&M Univ., College Station, TX 77843. Breeders seed has also been deposited in the U.S. Dept. of Agriculture lettuce collection held in Salinas, Calif.

\section{Literature Cited}

Farrara, B.F. and R.W. Michelmore. 1987. Identification of new sources of resistance to downy mildew in Lactuca spp. HortScience 22:647649.

Hulbert, S.H. and R.W. Michelmore. 1985. Linkage analysis for resistance to downy mildew (Bremia lactucae) in lettuce (Latuca sativa). Theor. and Applied Gen. 70:520-528.

Ilott, T.W., M.E. Durgan, and R.W. Michelmore. 1987. Genetics of virulence in Californian populations of Bremia lactucae (lettuce downy mildew). Phytopathology 77:1381-1386.

Johnson, A.G., S.A. Laxton, I.R. Crute, P.L. Gordon, and J.M. Norwood. 1978. Further work on the genetics of race specific resistance in lettuce (Lactuca sativa) to downy mildew (Bremia lactucae). Ann. Applied Biol. 82:257-264.
Jones, B.L. and P.W. Leeper. 1971. Sources of immunity from races 5 and 6 of lettuce downy mildew (Bremia lactucae). Plant Dis. Rptr. 55:794-796.

Leeper, P.W. 1963. 'Valmaine': A new downy mildew immune romaine lettuce variety. Texas A\&M Univ. Circ. no. L-610. College Station.

Leeper, P.W. 1969. TAMU 'Valrio': A new lettuce variety adapted to cold temperatures. Texas A\&M Univ. Circ. no. L-831. College Station.

Sleeth, B. and P.W. Leeper. 1966. Mildew resistant lettuce susceptible to a new physiologic race of Bremia lactucae in south Texas. Plant Dis. Rptr. 50:460.

Zink, F.W. and J.E. Duffus. 1969. Relationship of turnip mosaic virus susceptibility and downy mildew (Bremia lactucae) resistance in lettuce. J. Amer. Soc. Hort. Sci. 94:403-407. 